\title{
Keanekaragaman dan Kelimpahan Belalang dan Kerabatnya (Orthoptera) pada Dua Ekosistem Pegunungan di Taman Nasional Gunung Halimun-Salak
}

\author{
NETY VIRGO ERAWATI ${ }^{1)}$ DAN SIH KAHONO ${ }^{2)}$ \\ ${ }^{1)}$ Alumni Jurusan Biologi, FMIPA, Institut Pertanian Bogor \\ ${ }^{2)}$ Laboratorium Ekologi, Bidang Zoologi, Pusat Penelitian Biologi - LIPI
}

(diterima April 2010, disetujui Juli 2010)

\begin{abstract}
Diversity and Abundance of Grasshopper and Its Relatives (Orthoptera) on Two Mountainous Ecosystems of Gunung HalimunSalak National Park. A study on diversity and abundance of grasshopper and its relatives (Orthoptera) was conducted at two mountainous rainforest ecosystems (Mounts Kendeng and Botol) of Gunung Halimun-Salak National Park. A hundred meters of a line transect was used to sample and set up several insect traps (yellow pan, malaise, pit fall, bait pit fall, sweep net, and light traps), and insect sweepings as well. The light traps were set up at about fifty meters distance from the end of the sampling sites. A total individual collected by traps was combined on every comparable sampling site. Total individuals of the Orthoptera captured were 414; consisted of 25 species of 9 families. Both species diversity and number of families were higher at Mount Kendeng rather than Mount Botol. Number of species of each family usually similar except on family of Grillidae was much higher at Mount Kendeng. Species belong to Phasmidae was not recorded at Mount Kendeng, while species belong to both families of Gryllotalpidae and Tettigonidae were not captured at Mount Botol as well. Overal there was a difference in the species richness at each between. Shannon Diversity Index $\left(\mathrm{H}^{\prime}\right)$ and evenness (E) were higher at Mount Kendeng (2.44 and 0.81) rather than Mount Botol (1.80 and 0.66). Similarity Index of Jaccard (Cj) and Sorenson $(\mathrm{Cn})$ of both localities were similar $(0.40$ and 0.32$)$. Herbivores were most dominant at both localities (Phasmidae, Tetrigidae, Acrididae, Gryllidae, dan Gryllotalpidae), followed by omnivores (Blattidae), scavenger (Gryllacrididae), and predator (Mantidae).
\end{abstract}

KEY WORDS: diversity, grasshopper, mountainous ecosystems, Gunung Halimun-Salak National Park

\section{PENDAHULUAN}

Belalang dan kerabatnya ordo Orthoptera merupakan salah satu anggota dari kelompok serangga (kelas Insecta). Jenis-jenisnya mudah dikenal karena memiliki bentuk yang khusus misalnya belalang, jangkrik, dan kecoa. Nama belalang sudah sangat terkenal dalam sejarah kuno sebagai makanan manusia dan penghancur tanaman pertanian (LAI 2007), dan makanan bagi satwa liar (Kahono \& Amir 2003). Jenis belalang yang terkenal di Nusa Tenggara Timur, 
Lampung (Sumatera Selatan) dan beberapa daerah lainnya di Indonesia adalah Locusta migratoria atau belalang kembara, memiliki kemampuan melakukan peledakan populasi (outbreak) yang dapat menghancurkan ribuan hektar tanaman pertanian terutama padi dan jagung. Jenis-jenis belalang lainnya yang dikenal di Indonesia adalah belalang kayu (Valanga nigricornis), belalang ranting (Phobaeticus chani), belalang daun (Phyllium fulchrifolium), belalang sembah (Hierodula vitrea), kecoa (Periplaneta americana), dan jangkrik (Gryllus mitratus) (Koleksi MZB).

Belalang dan kerabatnya hidup di berbagai tipe lingkungan atau ekosistem antara lain hutan, semak/ belukar, lingkungan perumahan, lahan pertanian, dan sebagainya (Kalshoven 1981; Meyer 2001; Erniwati 2003). Di alam, belalang berperan sebagai pemangsa, pemakan bangkai, pengurai material organik nabati dan hewani, pemakan bagian tumbuhan hidup dan mati, dan musuh alami dari berbagai jenis serangga lainnya (Borror et al. 1992; Gwynne et al. 1996; Meyer 2001; Kahono \& Amir 2003).

Permasalahan pada penelitian belalang dan kerabatnya ordo Orthoptera adalah rendahnya pengetahuan keanekaragaman, sebaran, populasi dan aspek biologi dasar lainnya. Penelitian ekologi populasi termasuk monitoring fluktuasinya secara sistematis akan dapat meramalkan terjadinya regulasi naik-turunnya populasi dan outbreak. Untuk memantau keanekaragaman hayati perlu dilengkapi informasi jumlah individu (kelimpahan) dan fungsi atau peranannya pada suatu habitat dan ekosistem (Primack et al. 1988; Oliver \& Beatti 1992, 1996). Kelimpahan jenis serangga sangat ditentukan oleh aktifitas reproduksinya yang didukung oleh lingkungan yang cocok dan tercukupinya kebutuhan sumber makanannya. Kelimpahan dan aktifitas reproduksi serangga di daerah tropik sangat dipengaruhi oleh musim (Wolda \& Wong 1988), karena musim berpengaruh kepada ketersediaan sumber pakan dan kemampuan hidup serangga yang secara langsung mempengaruhi kelimpahan.

Ekosistem merupakan lingkungan biologi yang berisi organisme hidup, non-biotik, dan komponen fisik yang saling berinteraksi (Cambell \& Neil 2009). Perbedaan struktur dan komposisi penyusun suatu ekosistem menyebabkan perbedaan karakter ekosistem yang mempengaruhi keanekaragaman dan kelimpahan biota yang tinggal di dalamnya. Dataran tinggi biasanya mempunyai keanekaragaman dan kelimpahan yang lebih rendah jika dibandingkan dengan dataran rendah (Wolda 1983). Di daerah padang rumput, kelimpahan dan biomasa belalang berkurang pada musim semi (Porter \& Redak 1996). Setiap kelompok serangga mempunyai respon yang berbeda terhadap perubahan 
musim dan iklim (Wolda 1978, 1983; Kahono 2006). Belalang dan kerabatnya ordo Orthoptera sangat penting peranan dan fungsinya dalam menjaga keseimbangan ekosistem hutan (Gwynne et al. 1996; Erniwati 2003).

Hutan di kawasan Taman Nasional Gunung Halimun-Salak (TNGH-S) merupakan salah satu hutan tropik basah yang terdiri atas gugusan bukit dan pegunungan. Sampai saat ini, penelitian tentang kelompok belalang dan kerabatnya ordo Orthoptera di Indonesia masih terbatas jumlah dan aspek penelitiannya (Kalshoven 1981; Erniwati 2003). Penelitian keanekaragaman dan kelimpahan Orthoptera dilakukan di dua ekosistem pegunungan yang berbeda yaitu Gunung Kedeng (GK) dan Gunung Botol (GB), dengan maksud untuk mengetahui keanekaragaman dan kelimpahan jenis belalang dan kerabatnya ordo Orthoptera yang menempati dua ekosistem tersebut. Kajian terhadap peran setiap jenis belalang dan kerabatnya dapat memberikan pengetahuan tentang fungsi kelompok ini di lingkungannya. Hasil penelitian ini akan bermanfaat untuk penelitian monitoring terhadap perubahan iklim dan ekosistem di waktu yang akan datang, yang juga akan berguna bagi penyusunan berbagai kebijakan perlindungan dan pemanfaatan yang lestari sumber daya hayati khususnya jenis-jenis Orthoptera di TNGH-S.

\section{BAHAN DAN METODE}

Taman Nasional Gunung HalimunSalak (TNGH-S) secara geografis terletak antara $106^{\circ} 21^{\prime \prime}-106^{\circ} 38^{\prime \prime} \mathrm{BT}$ dan 6037"-651"LS (Djuwarsah 1997). Rata-rata curah hujan mencapai 4,181 mm per tahun (Kahono \& Noerdjito 2002) dan kelembaban rata-rata $80 \%$. Musim kering terjadi sekitar bulan Juni-Agustus (Manikam 1998). Ratarata suhu maksimum bervariasi antara $31^{\circ}-34,5^{\circ} \mathrm{C}$ dan suhu minimum antara $18,3^{\circ} \mathrm{C}-23,4^{\circ} \mathrm{C}$, sedangkan variasi suhu hariannya berkisar antara $24,7^{\circ} \mathrm{C}$ 26, $6^{\circ} \mathrm{C}$ (Djuwarsah 1997).

Pengambilan sampel Orthoptera dilakukan pada Januari, Februari, dan Maret 2003 di Gunung Kendeng (GK) (1.050-1.400 m dpl.) dan Gunung Botol (GB) (1.500-1.800 m dpl.). Pengambilan sampel dilakukan dengan membuat garis transek utama dengan panjang seratus (100) meter mengikuti jalur jalan setapak. Setiap sepuluh (10) meter pada transek utama dibuat transek sekunder tegak lurus sepanjang lima (5) meter ke kanan dan kiri. Pada titik-titik yang telah dibuat pada transek utama maupun transek sekunder dipasang secara acak perangkap serangga. Khusus pemasangan light trap dilakukan dengan jarak kira-kira lima puluh (50) meter dari ujung transek utama, untuk mengurangi pengaruhnya terhadap perangkap lainnya.

Pengumpulan spesimen dilakukan dengan menggunakan enam alat penangkap serangga, yaitu jaring se- 
rangga (sweep net) yang diayun sebanyak 15 ayunan, dengan ulangan sebanyak 5 kali; yellow pan trap sebanyak 10 buah yang dipasang selama 24 jam, malaise trap sebanyak 2 buah yang dipasang selama 2 hari, pitfall trap sebanyak 10 buah yang dipasang selama 2 hari, bait pitfall trap dengan umpan ayam busuk sebanyak 10 buah yang dipasang selama 24 jam, dan perangkap cahaya 100 watt (light trap) sebanyak 1 buah yang dipasang dari jam 18:30-21:30 WIB. Beberapa metode pengambilan sampel tersebut digunakan dalam penelitian ini agar kesempatan menangkap menjadi lebih tinggi. Beberapa penelitian memodifikasi beberapa metode yang sudah ada agar hasil tangkapan dapat diperoleh secara optimal dan dapat dibandingkan dan dianalisis secara kuantitatif (Toda \& Kitcing 1999; Borror et al. 1992). Identifikasi spesimen dilakukan secara morfospecies, dibandingkan dengan spesimen ilmiah yang telah teridentifikasi di Laboratorium Entomologi, Pusat Penelitian Biologi-LIPI dan menggunakan beberapa referensi ilmiah. Untuk mempermudah dalam analisis data maka hasil tangkapan dikelompokkan menurut waktu (Januari, Februari, dan Maret) serta tempat (GK dan GB).

Keanekaragaman hayati (biodiversity) sebagai kegiatan yang mengungkapkan jumlah jenis (kekayaan jenis atau species richness) yang ditemukan pada suatu komunitas/ ekosistem dan bagaimana kemerataan jumlah individu yang tersebar di antara jenis tersebut (evenness) (Magurran 1987). Pada penelitian keanekaragaman hayati ini menampilkan daftar jenis dan informasi lainnya, misalnya jumlah individu, fungsi, dan habitat tempat hidupnya. Dipilih cara mengukur keanekaragaman dengan menggunakan Indeks Keanekaragaman Shannon (Indeks Keanekaragaman Shannon-Wienner) memakai jumlah jenis, kelimpahan atau jumlah individu setiap jenis, dan menggabungkan keduanya. Nilai keanekaragaman bervariasi, semakin tinggi nilainya berarti keanekaragaman jenis semakin tinggi. Sebaran keanekaragaman (evenness) merupakan perbandingan antara nilai keanekaragaman yang diperoleh dengan nilai keanekaragaman maksimum. Nilai evenness berkisar antara 0 dan 1. Nilai 1 apabila antar species mempunyai kelimpahan sama atau seragam. Untuk mengetahui kesamaan jumlah species yang ditemukan pada dua lokasi, atau dua bulan yang berbeda pada lokasi yang sama, atau bulan yang sama pada lokasi yang berbeda menggunakan Indeks Kesamaan Sorenson, nilainya 0 sampai dengan 1, nilai 1 berarti jumlah species yang ditemukan di dua lokasi adalah sama dan nilai 0 berarti jumlah species yang ditemukan di dua lokasi adalah berbeda sama sekali. Perhitungan lain, kesamaan/kemiripan komposisi spesies antar lokasi (proporsi species yang sama antar lokasi) 
dapat dihitung dengan menggunakan Indeks Kesamaan Jaccard, nilainya 0 sampai dengan 1 , nilai 1 atau $100 \%$ berarti species yang ditemukan di dua lokasi memiliki kesamaan/kemiripan sempurna, dan nilai 0 atau $0 \%$ berarti tidak ada kemiripan sama sekali.

Sampel yang diperoleh dihitung jumlah individu $(\mathrm{N})$, jumlah famili $(\mathrm{F})$, dan jumlah jenisnya (S). Keanekaragaman Orthoptera dihitung berdasarkan indeks keanekaragaman Shannon (H'), sebaran keanekaragaman Shannon (E), indeks kesamaan Jaccard (Cj), indeks kesamaan Sorenson (Cn), serta kelimpahan relatif (KR) (Magurran 1987). Persamaan dalam perhitungan indeks tersebut adalah sebagai berikut:

$$
\begin{array}{ll}
\mathrm{H}^{\prime} & =-\sum n i / N \ln \mathrm{ni} / \mathrm{N} \\
\mathrm{E} & =\mathrm{H}^{\prime} \ln \mathrm{S} \\
\mathrm{Cj} & =\mathrm{j} /(\mathrm{a}+\mathrm{b}-\mathrm{j}) \\
\mathrm{Cn} & =2 \mathrm{jN} /(\mathrm{aN}+\mathrm{bN}) \\
\mathrm{KR} & =n \mathrm{n} / \mathrm{N} \times 100 \%
\end{array}
$$

Keterangan:

$$
\begin{aligned}
& \text { ni }=\text { jumlah individu pada } \mathrm{i} \text { jenis } \\
& \mathrm{j}=\text { jumlah jenis yang ditemukan } \\
& \text { pada lokasi a dan } \mathrm{b} \\
& \mathrm{a}=\text { jumlah jenis yang ditemukan } \\
& \text { pada lokasi a } \\
& \mathrm{b}=\text { jumlah jenis yang ditemukan } \\
& \text { pada lokasi b } \\
& \mathrm{jN}=\text { jumlah kelimpahan terendah } \\
& \text { yang terdapat pada lokasi a dan } \\
& \text { lokasi b } \\
& \text { aN = jumlah individu pada lokasi a }
\end{aligned}
$$

$\mathrm{bN}=$ jumlah individu pada lokasi $\mathrm{b}$

\section{HASIL DAN PEMBAHASAN}

\section{Keanekaragaman}

Dari data penelitian diperoleh 414 individu Orthoptera yang termasuk dalam 9 famili dan 25 jenis. Jumlah individu di GB lebih tinggi daripada GK, tetapi jumlah famili dan jenis lebih tinggi di GK daripada GB. Di GK diperoleh 136 individu yang termasuk dalam 8 famili dan 20 jenis dan GB diperoleh 278 individu yang termasuk dalam 7 famili dan 15 jenis. Jumlah individu, famili, dan jenis di GB lebih banyak pada Februari dibandingkan dengan Januari dan Maret. Di GK, jumlah individu lebih banyak pada Februari (53 individu) tetapi jumlah famili dan jenis lebih banyak pada Maret daripada bulan lainnya (Tabel 1).

Walaupun dalam penelitian ini memiliki jumlah jenis Orthoptera lebih sedikit dibandingkan yang dilakukan oleh Erniwati (2003), namun mempunyai informasi baru tentang perbedaan keanekaragaman dan kelimpaan Orthoptera pada dua ekosistem yang berbeda di TNGH-S, antara GK dan GB. Keanekaragaman Orthoptera yang tertinggi di GK ditunjukkan oleh banyaknya jumlah jenis yang ditemukan. Jumlah jenis Orthoptera di GK (20 jenis) lebih tinggi dibandingkan dengan GB (15 jenis). 
Tabel 1. Jumlah individu (N), famili (F), jenis (S), indeks keanekaragaman Shannon (H'), dan sebaran keanekaragaman Shannon (E) jenis Orthoptera di GK dan GB, TNGH-S

\begin{tabular}{cccccc}
\hline \hline Lokasi & Januari & Februari & Maret & Subtotal & Total \\
& & & & & \\
GK & 34 & 53 & 49 & 136 & \\
N & 5 & 6 & 8 & 8 & \\
F & 10 & 12 & 14 & 20 & \\
S & 2,09 & 1,99 & 2,08 & 2,44 & \\
H' & 0,91 & 0,80 & 0,79 & 0,81 & \\
E & & & & & \\
GB & 78 & 117 & 83 & 278 & \\
N & 5 & 6 & 5 & 7 & \\
F & 10 & 12 & 10 & 15 & \\
S & 1,62 & 1,77 & 1,47 & 1,80 & \\
H' & 0,70 & 0,71 & 0,64 & 0,66 & \\
E & & & & & \\
Subtotal & 112 & 170 & 132 & & \\
N & 6 & 6 & 9 & & \\
F & 14 & 18 & 19 & & \\
S & 1,99 & 2,09 & 2,10 & & 0,71 \\
H' & 0,76 & 0,72 & 0,71 & & \\
E & & & & & \\
\hline
\end{tabular}

Keterangan $\quad$ : GK = Gunung Kendeng; GB = Gunung Botol

Indeks keanekaragaman Shannon dan sebaran keanekaragaman Shannon (evenness) di GK $\left(\mathrm{H}^{\prime}=2,44\right.$ dan $\mathrm{E}=$ $0,81)$ lebih tinggi dibandingkan di GB $\left(\mathrm{H}^{\prime}=1,80\right.$ dan $\left.\mathrm{E}=0,66\right)$. Ada korelasi positif antara hasil penelitian Orthoptera dan kerabatnya ini dengan penelitian Atmowidi (2000), Suantara (2000), dan Utomo (2001) yang menyatakan bahwa keanekaragaman dan sebaran keanekaragaman serangga (Hymenoptera, Lepidoptera, dan Diptera) di GK lebih tinggi dibandingkan di GB.
Lebih rendahnya keanekaragaman Orthoptera di GB belum diketahui secara jelas. Tidak diukur curah hujan di kedua Gunung tersebut, hanya dari perkebunan teh terdekat (Malasari) curah hujan tidak menunjukkan perbedaan selama pengamatan. Curah hujan bulanan selalu di atas $100 \mathrm{~mm}$ mengindikasikan rendahnya musim kering (Whitmore 1984).

Dari data vegetasi menunjukkan bahwa keanekaragaman flora di GK lebih tinggi daripada GB (Manikam 1998; Atmowidi 2000; Suantara 2000). Literatur umum mengatakan bahwa 
keanekaragaman serangga berkorelasi positif dengan tingkat kompleksitas lingkungannya. Hutan yang lebih komplek (jenis tumbuhannya, iklim, ekosistemnya, dan landscape) biasanya memiliki keanekaragaman serangga yang lebih tinggi. Sejak tahun 2000 hutan di GB telah mengalami berbagai kemunduran karena penebangan dan alih fungsi hutan yang memicu tumbuhnya tumbuhan sekunder (semak, rumput, dan belukar) yang mengundang berbagai jenis serangga pendatang setelah suatu lingkungan baru terjadi. Jadi, lingkungan GB sebagai lingkungan hutan primer plus lingkungan baru. Keanekaragaman Orthoptera di GK $(2,44)$ lebih tinggi dari pada di GB $(1,80)$ yang berbeda dengan keanekaragaman kumbang di GB sedikit lebih tinggi daripada di GK, GB (3,59) dan GK $(3,55)$ (Maulinda 2003). Fenomena keanekaragaman yang demikian banyak terjadi pada lingkungan tropis (Wolda 1978).

Berdasarkan waktu pengambilan sampel, keanekaragaman tertinggi terjadi pada Maret $\left(\mathrm{H}^{\prime}=2,10\right)$, disusul Februari $\left(H^{\prime}=2,09\right)$, dan Januari $\left(H^{\prime}=\right.$ 1,99). Sebaran indeks keanekaragaman Orthoptera tertinggi terjadi pada Januari $(E=0,76)$, disusul Februari (E $=0,72)$, dan Maret $(\mathrm{E}=0,71)$ (Tabel

1). Hal ini menunjukkan bahwa pada Januari sebaran jumlah individu masing-masing jenis adalah tinggi (kelimpahan jumlah individu antar jenis paling tinggi), disusul berturut- turut pada Februari dan Maret. Belum cukup data yang dapat menerangkan secara jelas mengapa keanekaragaman pada Januari lebih tinggi daripada di bulan lainnya. Hal ini dapat disebabkan karena Januari lebih 'favorable' dilihat dari lebih banyaknya daun-daun muda (Apud, komunikasi pribadi) yang disukai oleh Orthoptera pada umumnya.

\section{Kesamaan}

Kesamaan jenis Orthoptera berdasarkan indeks kesamaan Jaccard antara GK dan GB sebesar 0,40 (Tabel 2). Berdasarkan pada bulan pengambilan sampel, kesamaan jenis Orthoptera pada Januari, Februari, dan Maret di GK berkisar antara 0,29-0,40, sedangkan di GB berkisar antara 0,470,82 . Indeks kesamaan jenis Orthoptera antar lokasi (GK dan GB) pada ketiga bulan tersebut berkisar antara 0,22-0,44.

Kesamaan jenis berdasarkan indeks kesamaan Sorenson di GK dan GB sebesar 0,32 (Tabel 3). Berdasarkan bulan pengambilan sampel, kesamaan jenis pada Januari, Februari, dan Maret di GK berkisar antara 0,30-0,53; sedangkan di GB berkisar antara 0,590,71. Indeks kesamaan Sorensen Orthoptera antar lokasi (GK dan GB) pada ketiga bulan tersebut berkisar antara 0,15-0,36. Kesamaan Sorrensen, menunjukkan bahwa proporsi jumlah spesies Orthoptera yang ditemukan di 
Tabel 2. Indeks kesamaan Jaccard (Cj) Orthoptera pada bulan Januari, Februari, dan Maret

\begin{tabular}{cccccccc}
\hline \hline Lokasi & $\begin{array}{c}\text { GK } \\
\text { Januari }\end{array}$ & $\begin{array}{c}\text { GK } \\
\text { Februari }\end{array}$ & $\begin{array}{c}\text { GK } \\
\text { Maret }\end{array}$ & $\begin{array}{c}\text { GB } \\
\text { Januari }\end{array}$ & $\begin{array}{c}\text { GB } \\
\text { Februari }\end{array}$ & $\begin{array}{c}\text { GB } \\
\text { Maret }\end{array}$ & $\begin{array}{c}\text { Total } \\
\text { GK }\end{array}$ \\
\hline $\begin{array}{c}\text { GK } \\
\text { Januari }\end{array}$ & 1 & & & & & & \\
$\quad$ GK & 0,29 & 1 & & & & & \\
$\begin{array}{c}\text { Februari } \\
\text { GK }\end{array}$ & 0,50 & 0,44 & 1 & & & \\
Maret & 0,30 & & & & \\
$\quad$ GB & 0,36 & 0,22 & 0,33 & 1 & & \\
$\begin{array}{c}\text { Januari } \\
\text { GB }\end{array}$ & 0,38 & 0,33 & 0,44 & 0,47 & 1 & & \\
$\begin{array}{c}\text { Februari } \\
\text { GB }\end{array}$ & 0,33 & 0,22 & 0,30 & 0,82 & 0,57 & 1 & \\
Maret & & & & & & 0,40 \\
Total GB & & & & & & & \\
\hline
\end{tabular}

Keterangan: GB = Gunung Botol; GK = Gunung Kendeng

Tabel 3. Indeks kesamaan Sorenson (Cn) Orthoptera pada bulan Januari, Februari, dan Maret

\begin{tabular}{|c|c|c|c|c|c|c|c|}
\hline Lokasi & $\begin{array}{c}\text { GK } \\
\text { Januari }\end{array}$ & $\begin{array}{c}\text { GK } \\
\text { Februari } \\
\end{array}$ & $\begin{array}{c}\text { GK } \\
\text { Maret }\end{array}$ & $\begin{array}{c}\text { GB } \\
\text { Januari }\end{array}$ & $\begin{array}{c}\text { GB } \\
\text { Februari } \\
\end{array}$ & $\begin{array}{c}\text { GB } \\
\text { Maret }\end{array}$ & $\begin{array}{c}\text { Total } \\
\text { GK } \\
\end{array}$ \\
\hline $\begin{array}{c}\text { GK } \\
\text { Januari }\end{array}$ & 1 & & & & & & \\
\hline $\begin{array}{c}\text { GK } \\
\text { Februari }\end{array}$ & 0,30 & 1 & & & & & \\
\hline $\begin{array}{c}\text { GK } \\
\text { Maret }\end{array}$ & 0,53 & 0,35 & 1 & & & & \\
\hline $\begin{array}{c}\text { GB } \\
\text { Januari }\end{array}$ & 0,32 & 0,15 & 0,21 & 1 & & & \\
\hline $\begin{array}{c}\text { GB } \\
\text { Februari }\end{array}$ & 0,21 & 0,36 & 0,19 & 0,59 & 1 & & \\
\hline $\begin{array}{c}\text { GB } \\
\text { Maret }\end{array}$ & 0,29 & 0,15 & 0,18 & 0,65 & 0,71 & 1 & \\
\hline Total GB & & & & & & & 0,32 \\
\hline
\end{tabular}


GK dan juga di GB adalah sebanyak 32\%. Kesamaan Jaccard, proporsi species Orthoptera yang ditemukan di GK dan juga ditemukan di GB sebanyak $40 \%$.

\section{Kelimpahan Jenis}

Nilai kelimpahan relatif (KR) di GK yang paling tinggi adalah famili Blattidae (73 individu; $\mathrm{KR}=53,68 \%$ ), kemudian disusul berturut-turut oleh Gryllidae (20 individu; KR = 14,71\%), dan Gryllacrididae (19 individu; KR = 13,97\%). Sedangkan KR di GB yang paling tinggi adalah famili Gryllidae $(101$ individu; $\mathrm{KR}=36,33 \%)$, kemudian disusul berturut-turut oleh Gryllacrididae (92 individu; KR = 33,09\%), dan Blattidae (52 individu; $\mathrm{KR}=18,71 \%$ ) (Tabel 4 dan Tabel 5).

Jenis yang lebih melimpah di GK adalah Blatta orientalis (Blattidae) (28 individu; $\mathrm{KR}=20,59 \%$ ), kemudian disusul berturut-turut oleh Graptoblatta sp. 1 (Blattidae) (22 individu;
$\mathrm{KR}=16,18 \%$ ), Rhaphidophora sp. 1 (Gryllacrididae) (16 individu; KR = 11,76\%), dan Pycnocelus sp. (Blattidae) (15 individu; $\mathrm{KR}=11,03 \%)$ (Tabel 4 dan Tabel 5).

Jenis yang lebih melimpah di GB adalah Nemobius sp. (Gryllidae) (101 individu; $\mathrm{KR}=36,33 \%$ ), kemudian disusul berturut-turut oleh Rhaphidophora sp. 1 (Gryllacrididae) (87 individu; KR $=31,29 \%$ ), Pycnocelus sp. (Blattidae) (20 individu; KR = 7,19\%) dan Captotetrix interuptus (Tetrigidae) (17 individu; $\mathrm{KR}=6,12 \%$ ). Empat jenis yang lebih melimpah dari pada yang lainnya di kedua lokasi tersebut adalah Nemobius sp. (106 individu; $\mathrm{KR}=25,60 \%)$, Rhaphidophora sp. 1 (103 individu; $\mathrm{KR}=24,88 \%$ ), Blatta orientalis (39 individu; $\mathrm{KR}=9,42 \%$ ), dan Pycnocelus sp. (35 individu; KR = 8,45\%) (Tabel 4 dan Tabel 5).

Tabel 4. Jumlah individu (N), jenis (S), dan kelimpahan relatif (KR) masingmasing famili Orthoptera di TNGH-S

\begin{tabular}{|c|c|c|c|c|c|c|}
\hline \multirow[b]{2}{*}{ Famili (F) } & \multicolumn{3}{|c|}{ GK } & \multicolumn{3}{|c|}{ GB } \\
\hline & $\begin{array}{c}\text { Jumlah } \\
\text { Individu } \\
(\mathrm{N})\end{array}$ & $\begin{array}{c}\text { Jumlah } \\
\text { Jenis (S) }\end{array}$ & KR (\%) & $\begin{array}{c}\text { Jumlah } \\
\text { Individu } \\
(\mathrm{N})\end{array}$ & $\begin{array}{c}\text { Jumlah } \\
\text { Jenis (S) }\end{array}$ & $\mathrm{KR}(\%)$ \\
\hline Acrididae & 13 & 3 & 9,56 & 8 & 3 & 2,88 \\
\hline Tetrigidae & 3 & 1 & 2,21 & 17 & 1 & 6,12 \\
\hline Gryllacrididae & 19 & 2 & 13,97 & 92 & 2 & 33,09 \\
\hline Blattidae & 73 & 4 & 53,68 & 52 & 5 & 18,71 \\
\hline Gryllidae & 20 & 6 & 14,71 & 101 & 1 & 36,33 \\
\hline Mantidae & 6 & 2 & 4,41 & 1 & 1 & 0,36 \\
\hline Gryllotalpidae & 1 & 1 & 0,74 & 0 & 0 & 0 \\
\hline Tettigoniidae & 1 & 1 & 0,74 & 0 & 0 & 0 \\
\hline Phasmidae & 0 & 0 & 0 & 7 & 2 & 2,52 \\
\hline
\end{tabular}

Keterangan: GK = Gunung Kendeng; GB = Gunung Botol; KR = Kelimpahan Relatif 
Tabel 5. Jumlah individu $(\mathrm{N})$ dan kelimpahan relatif $(\mathrm{KR})$ jenis* Orthoptera di GK dan GB, TNGH-S

\begin{tabular}{|c|c|c|c|c|c|c|}
\hline \multirow[b]{2}{*}{$\begin{array}{l}\text { Famili } \\
\text { Jenis }\end{array}$} & \multicolumn{2}{|c|}{ GK } & \multicolumn{2}{|c|}{ GB } & \multicolumn{2}{|c|}{ Total } \\
\hline & $\begin{array}{c}\text { Jumlah } \\
\text { individu } \\
\text { (N) }\end{array}$ & KR (\%) & $\begin{array}{l}\text { Jumlah } \\
\text { individu } \\
\text { (N) }\end{array}$ & $\mathrm{KR}(\%)$ & $\begin{array}{l}\text { Jumlah } \\
\text { individu } \\
(\mathrm{N})\end{array}$ & $\mathrm{KR}(\%)$ \\
\hline \multicolumn{7}{|l|}{ Acrididae } \\
\hline Phlaeoba sp. & 11 & 8,09 & 2 & 0,72 & 13 & 3,14 \\
\hline Erucius sp. & 1 & 0,74 & 1 & 0,36 & 2 & 0,48 \\
\hline Trilophidia sp. & 1 & 0,74 & 5 & 1,80 & 6 & 1,45 \\
\hline \multicolumn{7}{|l|}{ Tetrigidae } \\
\hline $\begin{array}{l}\text { Captotetrix } \\
\text { interuptus }\end{array}$ & 3 & 2,21 & 17 & 6,12 & 20 & 4,83 \\
\hline \multicolumn{7}{|l|}{ Gryllacrididae } \\
\hline Rhaphidophora sp. 1 & 16 & 11,76 & 87 & 31,29 & 103 & 24,88 \\
\hline Rhaphidophora sp. 2 & 3 & 2,21 & 5 & 1,80 & 8 & 1,93 \\
\hline \multicolumn{7}{|l|}{ Blattidae } \\
\hline Rhicnoda rugosa & 8 & 5,88 & 0 & 0 & 8 & 1,93 \\
\hline Blatta orientalis & 28 & 20,59 & 11 & 3,96 & 39 & 9,42 \\
\hline Graptoblatta sp. 1 & 22 & 16,18 & 9 & 3,24 & 31 & 7,49 \\
\hline Graptoblatta sp. 2 & 0 & 0 & 1 & 0,36 & 1 & 0,24 \\
\hline Pycnocelus sp. & 15 & 11,03 & 20 & 7,19 & 35 & 8,45 \\
\hline Epilampra sp. & 0 & 0 & 11 & 3,96 & 11 & 2,66 \\
\hline Gryllidae & 0 & 0 & 0 & 0 & 0 & 0 \\
\hline Trydactilus sp. & 1 & 0,74 & 0 & 0 & 1 & 0,24 \\
\hline Itara microcephala & 10 & 7,335 & 0 & 0 & 10 & 2,42 \\
\hline Nemobius sp. & 5 & 3,68 & 101 & 36,33 & 106 & 25,60 \\
\hline Muctibulus sp. & 2 & 1,47 & 0 & 0 & 2 & 0,48 \\
\hline Cyclopaglum sp. & 1 & 0,74 & 0 & 0 & 1 & 0,24 \\
\hline $\begin{array}{l}\text { Gymnogryllus } \\
\text { elegans }\end{array}$ & 1 & 0,74 & 0 & 0 & 1 & 0,24 \\
\hline \multicolumn{7}{|l|}{ Mantidae } \\
\hline Gonypeta punctata & 5 & 3,68 & 0 & 0 & 5 & 1,21 \\
\hline Ceratocrania macra & 1 & 0,74 & 0 & 0 & 1 & 0,24 \\
\hline Hierodula vitrea & 0 & 0 & 1 & 0,36 & 1 & 0,24 \\
\hline \multicolumn{7}{|l|}{ Gryllotalpidae } \\
\hline Gryllotalpa africana & 1 & 0,74 & 0 & 0 & 1 & 0,24 \\
\hline \multicolumn{7}{|l|}{ Tettigoniidae } \\
\hline Paragraecia sp. & 1 & 0,74 & 0 & 0 & 1 & 0,24 \\
\hline \multicolumn{7}{|l|}{ Phasmidae } \\
\hline Phasmidae sp. 1 & 0 & 0 & 1 & 0,36 & 1 & 0,24 \\
\hline Phasmidae sp. 2 & 0 & 0 & 6 & 2,15 & 6 & 1,69 \\
\hline \multicolumn{7}{|l|}{ Keterangan: } \\
\hline $\begin{array}{l}=\text { Pena } \\
=\text { Gunu }\end{array}$ & $\begin{array}{l}\text { jenis sec } \\
\text { endeno }\end{array}$ & morfospe & & & & \\
\hline$=\mathrm{Gunur}$ & otol & & & & & \\
\hline$=$ Kelim & n Relati & & & & & \\
\hline
\end{tabular}


Beberapa jenis yang hanya ditemukan di GK adalah Rhicnoda rugosa (Blattidae), Trydactilus sp., Itara microcephala, Muctibulus sp., Cyclopaglum sp., Gymnogryllus elegans (Gryllidae), Gonypeta punctata, Ceratocrania macra (Mantidae), Gryllotalpa africana (Gryllotalpidae), dan Paragraecia sp. (Tettigoniidae). Jenis yang hanya ditemukan di GB adalah Graptoblatta sp. 2, Epilampra sp. (Blattidae), Hierodula vitrea (Mantidae), Phasmidae sp. 1, dan Phasmidae sp. 2 (Phasmidae) (Tabel 4 dan Tabel 5).

Penelitian komunitas serangga selama setahun lebih oleh Kahono \& Woro (2002) menunjukkan adanya sinkronisasi antara hujan dan populasi serangga, namun dalam penelitian ini hanya dilakukan dalam waktu tiga bulan, maka tidak jelas apakah naikturunnya populasi selama pengamatan berkaitan dengan naik-turunnya curah hujan.

Kelimpahan jumlah individu antar spesies Orthoptera di GK lebih seragam $(0,81)$ dari pada di GB $(0,66)$. Hal yang mirip pada kelimpahan jumlah individu antar spesies kumbang di GK sedikit lebih seragam $(0,76)$ dari pada di GB $(0,72)$ (Maulinda 2003).

\section{Peranan Orthoptera}

Berdasarkan peranannya di alam, jenis-jenis dari ordo Orthoptera di TNGH-S berperan sebagai herbivora, omnivora, predator, dan pemakan bangkai (scavenger). Orthoptera yang berperan sebagai herbivora lebih dominan daripada kelompok lainnya. Orthoptera herbivora terdiri dari famili Acrididae, Tetrigidae, Tettigoniidae, Gryllotalpidae, dan Gryllidae. Orthoptera omnivora adalah famili Blattidae, scavenger famili Gryllacrididae, dan predator famili Mantidae.

Dari 171 individu (14 jenis) Orthoptera herbivora yang tertangkap, walaupun hanya 38 individu terdapat di GK namun keanekaragamannya sangat tinggi yaitu 12 jenis, sebaliknya dari 133 individu yang tertangkap di GB hanya terdiri dari 7 jenis. Dari 125 individu (6 jenis) Orthoptera omnivora yang tertangkap, jumlah individu dan jumlah jenisnya di GK dan GB tidak terlalu berbeda 73 individu (4 jenis) di GK dan 52 individu (5 jenis) di GB. Dari 111 individu (2 jenis) Orthoptera scavenger yang tertangkap, keduanya dijumpai di GK dan GB. Jumlah individu di GB (92 individu) jauh lebih banyak daripada di GK (19 individu). Dari 7 individu (3 jenis) Orthoptera predator yang tertangkap, dua jenis (6 individu) hanya dijumpai di GK, satu jenis (1 individu) hanya dijumpai di GB (Tabel 6).

Belalang dan kerabatnya ordo Orthoptera yang paling banyak ditemukan di TNGH-S (GK dan GB) berperan sebagai herbivora sebesar 
(41\%) yang terdiri dari famili Acrididae, Tetrigidae, Tettigoniidae, Gryllotalpidae, dan Gryllidae, yang diikuti berturut-turut oleh kelompok omnivora $30 \%$ (Blattidae), scavenger $27 \%$ (Gryllacrididae), dan predator $2 \%$
(Mantidae). Orthoptera yang berperan sebagai herbivora mendominasi di TNGH-S (Gambar 1). yang dilakukan oleh Rizali et al. (2002) yang mengemukakan bahwa serangga yang ditemukan di lahan persawahan tepian

Tabel 6. Pembagian peranan pada kelompok Orthoptera yang ditemukan di GK dan GB, TNGH-S

\begin{tabular}{lcccccc}
\hline \hline & \multicolumn{2}{c}{ GK } & \multicolumn{2}{c}{ GB } & \multicolumn{2}{c}{ Total } \\
\cline { 2 - 7 } PERAN & Jml. jenis & Jml. indiv. & Jml. jenis & Jml. indiv. & Jml. jenis & Jml. indiv. \\
\hline Herbivora & 12 & 38 & 7 & 133 & 14 & 171 \\
Omnivora & 4 & 73 & 5 & 52 & 6 & 125 \\
Scavenger & 2 & 19 & 2 & 92 & 2 & 111 \\
Predator & 2 & 6 & 1 & 1 & 3 & 7 \\
TOTAL & 20 & 136 & 15 & 278 & 25 & 414 \\
\hline
\end{tabular}

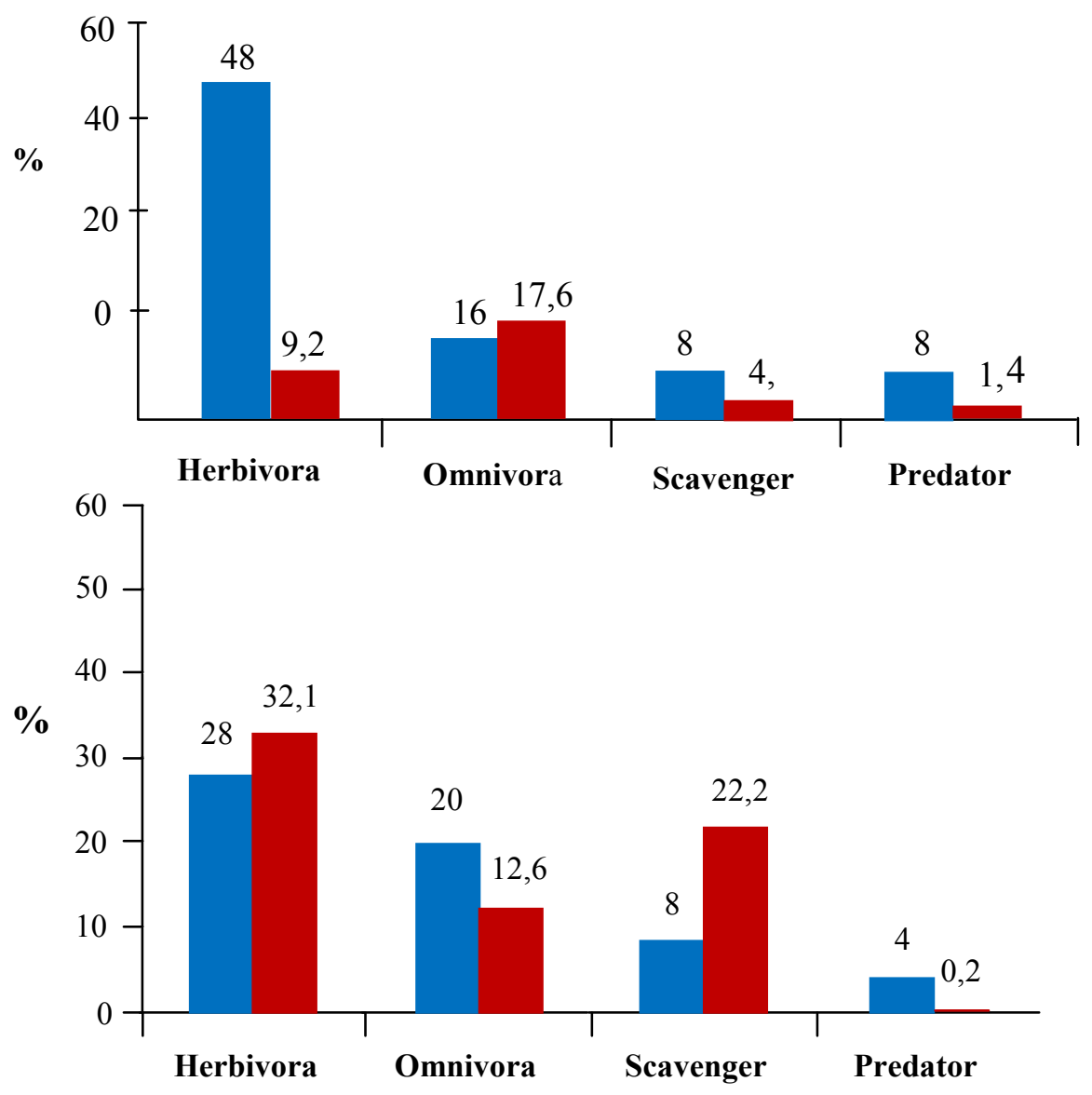

Gambar 1. Persentase dari total jumlah jenis (biru) dan kelimpahan individu (merah) Orthoptera yang dijumpai dalam penelitian berdasarkan peranannya di GK (kiri) dan GB (kanan) 
hutan dalam wilayah TNGH-S didominasi oleh serangga herbivora. Serangga herbivora merupakan pemakan tumbuhan dan dapat menempati hampir semua tipe habitat, baik pada kanopi atau tajuk pohon dan belukar. Orthoptera omnivora sebagai pemakan segala jenis makanan, biasanya lebih dikenal sebagai perombak yang menempati hampir semua tipe habitat hutan seperti serasah dan material organik tumbuhan. Orthoptera scavenger merupakan pemakan bangkai, biasanya hidup pada permukaan tanah dan serasah (Meyer 2001).

Kecuali scavenger, persentase jenis Orthoptera yang bersifat herbivora, omnivora, dan predator di GK lebih tinggi daripada yang terdapat di GB. Hal demikian juga terjadi pada kelimpahan individu omnivora dan predator. Sebaliknya, kelimpahan individu herbivora, scavenger di GB lebih tinggi daripada di GK (Gambar 1). Walaupun tidak begitu jelas alasannya namun kondisi ini menunjukkan bahwa lingkungan di GK lebih baik daripada GB (Simbolon \& Mirmanto 1997).

\section{KESIMPULAN}

Berdasarkan hasil yang telah diperoleh dapat disimpulkan bahwa. Keanekaragaman belalang dan kerabatnya di Gunung Kendeng lebih tinggi (20 jenis dan 8 famili) daripada Gunung Botol (15 jenis dan 7 famili), tetapi kelimpahannya lebih tinggi di Gunung Botol (278 individu) daripada
Gunung Kendeng (136 individu). Jenis yang melimpah di Gunung Kendeng adalah Blatta orientalis, Rhaphidophora sp 1, Pycnocelus sp., Phlaeoba sp., dan Itara microchepala, sebaliknya di Gunung Botol adalah Nemobius sp., Rhaphidophora sp 1, dan Pycnocelus sp. Jenis-jenis yang termasuk famili Phasmidae tidak ditemukan di Gunung Kendeng, sebaliknya yang termasuk Gryllotalpidae dan Tettigonidae tidak ditemukan di Gunung Botol. Sepuluh jenis (Rhicnoda rugosa, Trydactilus sp., Itara microcephala, Muctibulus sp., Cyclopaglum sp., Gymnogryllus elegans, Gonypeta punctata, Ceratocrania macra, Gryllotalpa africana, and Paragraecia sp.) hanya ditemukan di Gunung Kendeng. Lima jenis (Graptoblatta sp. 2, Epilampra sp., Hierodula vitrea, Phasmidae sp. 1, and Phasmidae sp. 2) hanya ditemukan di Gunung Botol. Kelompok belalang dan kerabatnya yang dominan di Gunung Kendeng dan Botol adalah jenis-jenis yang berperan sebagai herbivora daripada omnivora, scavenger, dan predator.

\section{UCAPAN TERIMA KASIH}

Saudara Sarino (teknisi Laboratorium Entomologi, Bisang Zoologi) dan Hendi (Citalahab, Malasari) yang telah membantu pelaksanaan penelitian di lapangan. Dra. Erniwati dan teknisi laboratorium Entomologi, Bidang Zoologi, Pusat Penelitian Biologi-LIPI yang telah membantu sorting, 
mounting, dan identifikasi. Kepala Balai Taman Nasional Gunung Halimun atas ijin yang telah diberikan. Dr. Tri Atmowidi, M.Si. atas bimbingannya yang telah dilakukan. Kepada mereka semua kami mengucapkan banyak terima kasih.

\section{DAFTAR PUSTAKA}

Atmowidi T. 2000. Keanekaragaman morfospesies Hymenoptera parasitoid dan senyawa Antiherbivora di Taman Nasional Gunung Halimun, Jawa Barat [tesis]. Bogor: Institut Pertanian Bogor.

Borror DJ, Triplehorn CA, Johson NF. 1992. Pengenalan Pelajaran Serangga. Partosoedjono S, penerjemah. Yogyakarta: Gadjah Mada University Press. Terjemahan dari: An Introduction to Study of Insect.

Borror DJ, White RE. 1970. Field Guide Insects. New York: Houghton Mifflin Company.

Campbell, Neil A. 2009. Biology concepts and connections. $6^{\text {th }}$ (ed.), Benjamin-Cummings Pub Co.

Djuwarsah M. 1997. The Soil of Gunung Halimun National Park. Reasearch and Conservstion of Biodiversity in Indonesia. In: The Inventory of Natural Resources in Gunung Halimun National Park. Vol. II. Biodiversity Conservation Project.
Erniwati. 2003. Belalang (Orthoptera) dan kekerabatannya. Di dalam: Amir M, Kahono S (ed.). Serangga Taman Nasional Gunung Halimun Jawa Barat. Biodiversity Conservation Project. Hal. 63-76.

Gwynne DT, DeSutter L, Flook P, Rowell H. 1996. Orthoptera. Crickets, katydids, grasshoppers, etc. Version 01 January 1996.

Kahono S. 2006. Respon adaptif kumbang lembing pemakan daun Henosepilachna vigintictopuchtata (Fabricius) (Coleoptera: Coccinellidae: Epilachninae) dan tumbuhan inangnya terhadap musim kemarau di daerah beriklim tropis kering Pasuruan dan Malang - Jawa Timur. Berita Biologi 8(3): 193200.

Kahono S, Amir M. 2003. Ekosistem dan khasanah serangga Taman Nasional Gunung Halimun. Di dalam: Amir M \& Kahono S. (ed.), Serangga Taman Nasional Gunung Halimun Jawa Barat. Biodiversity Conservation Project. Hal. 1-22.

Kahono S, Noerdjito WA. 2002. Fluctuation of Rainfall and Insect Community in Gunung Halimun National Park, West Java. Research and Conservation of Biodiversity in Indonesia, Vol. IX, 157-169.

Kalshoven LGE. 1981. Pests of Crops in Indonesia. Laan PA van der, penerjemah. Jakarta : PT Ichtiar Baru-van Hoeve. Terjemahan dari 
: De Plagen van de Cultuurgewassen in Indonesie.

LAI. 2007. Holy Bible. New International Version. Jakarta: Lembaga Alkitab Indonesia..

Magurran AE. 1987. Ecological Diversity and Its Measurement. London: Chapman and Hill.

Makihara H, Noerdjito WA, Sugiarto. 2002. Longicorn Beetles from Gunung Halimun National Park, West Java, Indonesia from 19972002 (Coleoptera, Disteniidae and Cerabycidae). Bulletin of Forestry and Forest Products Research Institute 1 (3, 384): 189-223.

Manikam PJ. 1998. Gunung Halimun National Park Plan Book I. Research and Conservation of Biodiversity in Indonesia. Vol III. Bogor: Information System and Park Management of Gunung Halimun National Park.

Maulinda D. 2003. Keragaman Kumbang di Taman Nasional Gunung Halimun, Jawa Barat [skripsi]. Bogor: IPB.

Meyer JR. 2001. Orthoptera. http: //www. cals. nscuedu/ course/ ent425/ compendium/ orthop.htmal [diakses 22 Maret 2002].

Oliver L, Beatti AJ. 1992. A possible method for the rapid assesment of biodiversity. Conservation Biology 7: 562-568.

Oliver L, Beatti AJ. 1996. Invertebrate morphospecies as surrogates for species: a case of study. Conservation Biology 10 (1): 99-109.

Primack RB, Supriatna J, Indrawan M, Kramadibrata P. 1988. Biologi Konservasi. Jakarta: Yayasan Obor Indonesia.

Porter EE, Redak RA. 1996. Shortterm recovery of grasshopper communites (Orthoptera: Acrididae) of a California native grassland after prescribe burning. http://www.ags.uci.edu/eporter/res earch.html. [diakses 3 Februari 2003].

Rentz DCP. 1996. Grasshopper Country. Australia: CSIRO.

Rizali A, Buchori D, Triwidodo H. 2002. Keanekaragaman serangga pada lahan persawahan-tepian Hutan: Indikator kesehatan lingkungan. Hayati 9(2):41-47.

Simbolon H \& Mirmanto E. 1997. Altitudinal zonation of the forest vegetation in GHNP, West Java. In: Research and Conservation of Biodiversity in Indonesia vol. II. The Inventory of Natural Resources in GHNP. p. 14-35.

Suantara IN. 2000. Keragaman kupukupu (Lepidoptera) di Taman Nasional Gunung Halimun, Jawa Barat [skripsi]. Bogor: Fakultas Pertanian IPB.

Toda MJ, Kitcing RL. 1999. Forest Ecosystem: the assessment of plant and animal biodiversity in forest ecosystem. International Biodiversity Observation Year. 
Utomo S. 2001. Keanekaragaman Ordo Diptera (Insecta) di Gunung Kendeng dan Gunung Botol, Taman Nasional Gunung Halimun, Jawa Barat [skripsi]. Bogor: Institut Pertanian Bogor, Fakultas Matematika dan Ilmu Pengetahuan Alam.

Whitmore TC. 1984. Tropical rain Forests of the Far East. $2^{\text {nd }}$ ed. Oxford: Clarendon Press.

Willemse LPM. 2001. Fauna Malesiana Guide to Pest Orthoptera of Indomalayan Region. Netherlands: Buckhuy Publiser.
Wolda H. 1978. Seasonal fluctuation in rainfall, food and abundance of tropical insects. Journal of Animal Ecology 47:369-381.

Wolda H. 1983. Diversity, diversity indices and tropical cockroaches. Oecologia 58:290-298.

Wolda H, Wong H. 1988. Tropical insect diversity and seosonality Sweep samples vs Light trap. Prociding Entomology 91(2):203216. 